\title{
Assesment of Prenatal Distress and Depressive Symptoms in Women with Gestational Diabetes
}

\author{
Merve ÇAĞLAR ๑ 凶, Ümran YEŞILLTEPE OSKAY ๑ \\ ${ }^{1}$ Bilecik Şeyh Edebali University School of Nursing, Department of Women's Health and Diseases Nursing, Bilecik, Turkey \\ ${ }^{2}$ Istanbul University Cerrahpasa Florence Nightingale Faculty of Nursing, Department of Women's Health and Diseases Nursing, Istanbul, Turkey \\ Cite this article as: Çağlar M, Yeşiltepe Oskay Ü. Assesment of Prenatal Distress and Depressive Symptoms in Women with Gestational Diabetes. Türk Diyab Obez 2019;2: 73-78.
}

\begin{abstract}
Aim: Diabetes Mellitus is one of the most common health problem in pregnancy. The study was designed to assess the prenatal distress and depression symptoms prevalence during pregnancy with or without gestational diabetes mellitus (GDM).

Material and Methods: This study was a comparative descriptive. Three hundred and eight pregnant women (155 healty and 153 with GDM) attending at The Health Science University Hospital in Istanbul, Turkey, participated in the study. A semi-structured questionnaire form were used for sociodemografic, obstetric and diabetic data. Multidimensional Scale of Perceived Social Support (MSPSS) were used to measure social support, Perinatal Distress Scale (PDS) were used to measure perinatal distress and Edinburgh Postpartum Depression Scale (EPDS) were used to measure depression symptoms.

Results: PDS and EPDS score was significantly higher in GDM subjects compare to healty (without GDM) subjects. A significant negative correlation was found between MSPSS and EPDS scores in both groups. There was a significant positive correlation between the PDS and EPDS scores in both groups.

Conclusion: The women with GDM have more distress and depression symptoms. Higher rate of depression and distress in pregnancy deserves medical attention especially women with GDM, so awareness of health care professional should be increased.
\end{abstract}

Key Words: Pregnancy, Gestational diabetes, Depression, Social support

\section{Gestasyonel Diyabetli Kadınlarda Prenatal Distres ve Depresyon Düzeylerinin Belirlenmesi}

\section{ÖZET}

Amaç: Gestasyonel diabetes mellitus (GDM) gebelikte en yaygın görülen sağlık problemlerinden biridir. Bu çalışmanın amacı gestasyonel diyabetli kadınlarda prenatal distres ve depresyon düzeylerinin belirlenmesidir.

Gereç ve Yöntemler: Çalışma karşılaştırmalı tanımlayıcı türdedir. İstanbul'da bir üniversite hastanesinde takip edilen 308 gebe (155 sağlıklı, 153 gestasyonel diyabetli) dahil edilmiştir. Sosyodemografik, obstetrik ve diyabetik veriler için yarı yapılandırılmış görüşme formu kullanılmıştır. Ayrıca Çok Boyutlu Algılanan Sosyal Destek Ölçeği (ÇBASDÖ), Perinatal Distres Ölçeği (PDÖ) ve Edinburgh Doğum Sonrası Depresyon Ölçeği (EDSDÖ) kullanılmıştır.

Bulgular: PDÖ ve EDSDÖ skoru GDM’li gebelerde sağlıklı gebelere göre anlamlı derecede yüksek bulundu. Her iki grupta da ÇBASDÖ ile EDSDÖ arasında negatif yönde anlamlı bir ilişki bulundu. PDÖ ve EDSDÖ arasında pozitif yönde anlamlı bir ilişki olduğu belirlendi.

Sonuç: GDM'li kadınlar daha fazla distres ve depresyon belirtileri gösterirler. Gebelikte distres ve depresyon düzeyinin yüksek olması özellikle diyabetli kadınlarda daha fazla tıbbi sorunlar yaşanmasına neden olmaktadır. Bu nedenle sağlık bakım profesyonellerinin farkındalığı artırılmalıdır.

Anahtar Sözciikler: Gebelik, Gestasyonel diyabet, Depresyon, Sosyal destek

This study was presented as a verbal presentation at the I. International and II. National Women Health Nursing Congress held in Istanbul on 23-24 March 2018. ORCID: Merve Çağlar / 0000-0003-2626-4170, Ümran Yeşiltepe Oskay / 0000-0002-6606-9073 


\section{INTRODUCTION}

Pregnancy period counted as a life crisis period because of important biological and psychological adaptations $(1,2)$. Although many women can easily adapt to these changes, some of them can have some health problems (3).

Diabetes Mellitus affects approximately 0.6 to $15 \%$ of women all over the world (4-6). Gestational diabetes is defined as carbohydrate intolerance (7-9). In Turkey, the prevalence of GDM has been found between 1.2\%-30.8\% $(10,11)$.

Distress, depression and diabetes are common in pregnancy (12). There are many biological and psychosocial mechanisms that explain the relationship between GDM, antenatal distress and depression (13). The stress-enhancing effect of hyperglycemia and insulin on the thyroid and the psychological burden of chronic disease on pregnancy can be given as examples $(13,14)$.

GDM leads to increases the incidence of stress and anxiety in pregnant women and some adverse maternal and foetal complications in the prenatal and postnatal period. Although the association between stress, depression and diabetes is well established, nurses and other health care team members have less information about antenatal distress and depression relationship (12). A few studies examined the GDM and prenatal distres-depresion symptoms in the literature. The purpose of the study is to assess perinatal distress and depression level in women with or without gestational diabetes. It may be possible to prevent many maternal and foetal complications by planning nursing care carefully in women with GDM.

\section{MATERIALS and METHODS}

\section{Ethical Consideration}

The protocol was aproved by the written Ethical Review Committee of The Health Science University Hospital in Istanbul, Turkey. Written consent was received from all subjects. Objectives and the procedure of study were oriented to the subjects, including their right to refuse and withdraw at any stage of the study. All information and data collected for the study, were deemed confidential.

\section{Study Design}

The research is designed as a descriptive and comparative study.

\section{Sampling and setting}

The study was conducted from July 2015 and September 2016 at outdoor department of The Health Science University Hospital.

\section{Research participation criteria;}

For the diabetic group: 18 years of age and over, willing to participate in the study, $24^{\text {th }}$ and over week on pregnancy, with gestational diabetes, no psychiatric disease and speaks Turkish.

For the healthy group: 18 years of age and over, willing to participate in the study, 24 and over week on pregnancy, speaks Turkish, and have no chronic or psychiatric disease.

Sample size was calculated with using power analysis 3.1.7. version, 95\% confidence interval, 5\% error margin, 0.5 effect size and $80 \%$ power. 145 for GDM group and 150 for healthy group were taken. The study was conducted with 155 healty, 153 diabetic pregnant women who were available for participation criteria.

\section{Measurements}

Data on sociodemographic, obstetric, diabetic informations was collected with semi structured questionnaire form including 37 questions about (31 questions in healty group questionnaire form because there are no questions about diabetes). Multidimensional Perceived Social Support Scale, Perinatal Distress Scale and Edinburgh Postpartum Depression Scale were used to measure social support, prenatal stres and prenatal depression symptoms.

Questionnaire form: The semi structured questionnaire form has 37-questions (31 questions with no diabetes) that includes data such as sociodemographic, obstetric, diabetic status of pregnancies. It was structured according to the literature by the researcher $(9,15,16)$.

Multidimensional Scale of Perceived Social Support: It was developted by Zimet et al. in 1988 to measure the adequacy of social support consisting of three sub-dimensions such as "family", "friend" and "private person". It consists of 12 items in total. On a Likert-type scale, scores of 1 (absolutely no) to 7 (absolutely yes) are given to each item. The score of the subdimensions is between 4 and 28, and the score of the scale is between 12 and 84 . Validity and reliability studies have been carried out in Turkey (17).

Prenatal Distress Scale: It was developed by Yali and Lobel (1999) in order to assess specific pregnancy related concerns such as pregnancy related medical problems, physical symptoms, somatic changes, parenting, birth and baby health. The validity and reliability study for Turkey was carried out by Durna Z., Akın S. and Yüksel F. Participants are asked to respond by marking one of the choices listed as "None" (0), "Some" (1) and "Too many" (2) by reading each expression on the scale. The high score of the scale indicates that the perceived prenatal distress is high (18). 
Edinburgh Postpartum Depression Scale (EDSSS): The scale developed by Cox et al. in 1987 . The validity and reliability study for Turkey was carried out by Engindeniz et al. in 1996. It was developed to determine the postpartum depression risk. However, research by Murray and Cox found that scale also could be effective to determine the depression in the pregnancy period. The scale is of the four-point likert type and consists of 10 items. The cutoff point of the scale was 13 . Higher scores indicate that the depressive risk is greater (16).

\section{Data Collection}

The data was collected by face-to-face interview technique.

\section{Data Analysis}

The data were analyzed in the SPSS version 15 database. Descriptive statistical methods (mean, standard deviation, mode, median, frequency, minimum, maximum), Chi Square and Mann-Whitney U tests were used in statistical analysis of the data.

\section{Limitations of the Research}

The study was conducted in one center and the number of samples was low.

\section{RESULTS}

Mean age of the study population were $29.24 \pm 4.93$ with GDM and $29.00 \pm 4.87$ without GDM, (p>0.999). Mean of education years were $11.11 \pm 4.15$ with GDM and $11.43 \pm$ 3.99 without GDM, $(\mathrm{p}>0.999)$. Mean gestational age were $30.00 \pm 3.86$ with GDM and $31.00 \pm 4.64$ without GDM, (p> 0.999) (Table 1).

Mean of MSPSS score was quite higher in both groups as the subscale and the total score (with GDM 68.79; without GDM 71.84 ) and there was no significant difference between the groups ( $p>0.999)$. The prenatal distress scale score mean was significantly higher in GDM subjects compared to healthy subjects (GDM group $12.44 \pm 5.16$, without GDM group $7.90 \pm 5.09, \mathrm{p}<0.001)$. The EPDS score mean was also significantly higher in GDM group than the healthy group (GDM group $9.96 \pm 4.97$, HP group $7.56 \pm 5.58, \mathrm{p}<.001$ ), (Table 2).

There was no significant correlation between the PDS and MSPSS score means in both groups ( $p>0.999)$. There was a statistically significant negative and poor correlation between EPDS and MSPSS score mean in both groups $(\mathrm{p}<0.001)$, (Table 3).

A statistically significant corelation was found between the PDS and the EPDS both the gestational diabetes group and the healthy pregnant group in a poor and positive way $(\mathrm{p}<0.001)$, (Table 3$)$.

\section{DISCUSSION}

The primary aim of the study was to assess the prenatal distress and depression symptoms in pregnant women with gestational diabetes mellitus. Result of the study was alarming. Prenatal distress and depression are more common in women gestational diabetes and prenatal distress increases the depression symptoms. After controlling the associated factors like age, education, gravidity and gestational week; women with GDM were three to four times more prone to have depression than women without GDM (19). In our study, these associated factors (age, education, gravidity, gestational week) can be controlled and no statistically significant difference was found between the women with gestational diabetes and healthy pregnancies groups ( $p>0.999$ ), (Table 1 ).

Many studies have indicated that pregnancies with high social support levels associated with fewer depressive symptoms during pregnancy $(6,18,20)$. According to our study, the social support levels of our pregnant women are quite high (Table 2). In the study by Giurgescu et al. (19), social support scale score was also higher. In the study by Ölçer et al. (6), social support scale mean score was also higher. There was no significant difference between the two groups about the effect of social support scores on prenatal distress level in our study (Table 3). In the study by Virit et al. (21), there was no significant relationship between the social support and distress. On the other hand, social support is seen as a protective barrier for depression in pregnancy $(12,22)$. In our study, there was a significant poor and negatively correlation between depression and social support in both groups (Table 3). In the study of Biratu and Haile (15), more depressive symptoms were reported in the cases with low social support. It is assumed that with higher social support, the prenatal depression incidence decreases, but prenatal distress incidence is not affected.

Our study found that prenatal distress significantly higher in gestational diabetic women compared to healthy pregnancies (Table 2). In the literature, it was indicated that the stress level was higher in gestational diabetics compared to healthy pregnancies (23-25). Many biological and psychosocial mechanisms are known to explain the relationship between GDM, antenatal distress and depression. The stress enhancing effect of hyperglycemia and insulin on the thyroid and the psychological burden of chronic disease on pregnancy can be given as examples $(13,26)$. Prenatal depression was found significantly higher in GDM group compared to healthy group according to our study (Table 2). In our study, depression symptoms were found that $30.7 \%$ in GDM group and $18.7 \%$ in healthy group according to EPDS mean score. 
Table 1: Distribution of sociodemographic, obstetric and diabetic characteristics of gestational diabetic and healthy pregnancies.

\begin{tabular}{|c|c|c|c|c|c|c|}
\hline \multirow[t]{2}{*}{ Variables } & \multicolumn{2}{|c|}{$\begin{array}{l}\text { The women with GDM } \\
(n=153)\end{array}$} & \multicolumn{4}{|c|}{$\begin{array}{l}\text { Healthy Group } \\
\quad(n=155)\end{array}$} \\
\hline & $\overline{\mathrm{X}}(\mathrm{SD})$ & Min-Max & $\overline{\mathrm{X}}(\mathrm{SD})$ & Min-Max & $\mathrm{Z}_{\mathrm{MWU}}$ & $\mathbf{p}$ \\
\hline Age & $29.24(4.93)$ & $19-44$ & $29.00(4.87)$ & $18-43$ & -0.32 & $>.999$ \\
\hline Marriage Year & $6.57(5.40)$ & $1.0-25$ & $6.31(4.97)$ & $0.6-21$ & -0.80 & $>.999$ \\
\hline Education Year & $11.11(4.15)$ & $5.0-15$ & $11.43(3.99)$ & $5.0-15$ & -0.61 & $>.999$ \\
\hline Gravida & $2.00(1.04)$ & $0.0-5.0$ & $2.01(1.08)$ & $0.0-6.0$ & -0.04 & $>.999$ \\
\hline Parity & $0.76(0.85)$ & $0.0-3.0$ & $0.73(0.80)$ & $0.0-3.0$ & -0.14 & $>.999$ \\
\hline Gestational Age & $30.0(3.86)$ & $24.0-39.0$ & $31.00(4.64)$ & $24.0-41.0$ & -1.84 & $>.999$ \\
\hline Variables & $\mathbf{n}$ & $\%$ & $\mathbf{n}$ & $\%$ & $\chi^{2}$ & $\mathbf{p}$ \\
\hline \multicolumn{7}{|l|}{ Working Status } \\
\hline Working & 73 & 47.7 & 76 & 49.0 & 0.054 & $>.999$ \\
\hline Not working & 80 & 52.3 & 79 & 51.0 & & \\
\hline \multicolumn{7}{|l|}{ Family Type } \\
\hline Core Family & 136 & 88.9 & 132 & 85.2 & 0.947 & $>.999$ \\
\hline Extended Family & 17 & 11.1 & 23 & 14.8 & & \\
\hline \multicolumn{7}{|l|}{ Problem in Marriage } \\
\hline Yes & 9 & 5.9 & 11 & 7.1 & 0.187 & $>.999$ \\
\hline No & 144 & 94.1 & 144 & 92.9 & & \\
\hline \multicolumn{7}{|l|}{ Prepregnancy BMI } \\
\hline Normal weight $(\mathrm{BMI}<25)$ & 120 & 78.4 & 127 & 81.9 & 0.595 & $>.999$ \\
\hline Overweight (BMI $\geq 25)$ & 33 & 21.6 & 28 & 18.1 & & \\
\hline \multicolumn{7}{|l|}{ Gestational Weight Gain } \\
\hline Under 14 & 116 & 75.8 & 128 & 82.6 & 2.140 & $>.999$ \\
\hline 14 and Over & 37 & 24.2 & 27 & 17.4 & & \\
\hline \multicolumn{7}{|l|}{ Planned Pregnancy } \\
\hline Yes & 109 & 71.2 & 124 & 80.0 & 3.206 & $>.999$ \\
\hline No & 44 & 28.8 & 31 & 20.0 & & \\
\hline \multicolumn{7}{|l|}{ GDM Treatment Type } \\
\hline Diet & 132 & 86.3 & & & & \\
\hline Insulin+Diet & 18 & 11.8 & & & & \\
\hline \multicolumn{7}{|l|}{ Diabetes in the family } \\
\hline Yes & 63 & 41.2 & & & & \\
\hline No & 87 & 56.9 & & & & \\
\hline
\end{tabular}

GDM: Gestasyonel Diyabetes Mellitus, $\mathbf{Z}_{\text {MwU }}$ : Mann-Whitney U, $\chi^{2}$ : Chi square

Table 2: Comparison of scale intervals of the MSPSS, PDS and EPDS of gestational diabetes and healthy pregnancies.

\begin{tabular}{lcccccc}
\hline & \multicolumn{2}{c}{$\begin{array}{c}\text { The women with GDM } \\
(\mathbf{n}=\mathbf{1 5 3})\end{array}$} & \multicolumn{3}{c}{$\begin{array}{c}\text { Healthy Group } \\
(\mathbf{n}=\mathbf{1 5 5})\end{array}$} \\
\cline { 2 - 7 } & $\overline{\mathbf{X}}(\mathbf{S D})$ & Min-Max & $\overline{\mathbf{X}}(\mathbf{S D})$ & Min-Max & $\mathbf{Z}_{\text {MwU }}$ & $\mathbf{p}$ \\
\hline MSPSS & $68.79(16.44)$ & $16.0-84.0$ & $71.84(14.14)$ & $19.0-84.0$ & -2.02 & $>.999$ \\
\hline PDS & $12.44(5.16)$ & $0.0-25.0$ & $7.90(5.09)$ & $0.0-25.0$ & -7.62 & $<.001$ \\
\hline EPDS & $9.96(4.97)$ & $0.0-28.0$ & $7.56(5.58)$ & $0.0-28.0$ & -4.42 & $<.001$ \\
\hline
\end{tabular}

$\mathrm{Z}_{\mathrm{MWU}}:$ Mann-Whitney U 
Table 3: Comparison of PDS and EPDS scores and MPSS scores in gestational diabetic and healthy pregnancies and comparison of PDS scores and EPDS scores between gestational diabetic and healthy pregnancies.

\begin{tabular}{|c|c|c|c|c|}
\hline & \multicolumn{4}{|c|}{ MSPSS } \\
\hline & \multicolumn{2}{|c|}{ The women with GDM $(n=153)$} & \multicolumn{2}{|c|}{ Healthy Group (n=155) } \\
\hline & $\mathbf{r}$ & $\mathbf{p}$ & $\mathbf{r}$ & $\mathbf{p}$ \\
\hline PDS $^{*}$ & -0.12 & $>.999$ & -0.13 & $>.999$ \\
\hline \multirow[t]{4}{*}{ EPDS $^{*}$} & -0.40 & $<.001$ & -0.37 & $<.001$ \\
\hline & \multicolumn{4}{|c|}{ EPDS } \\
\hline & \multicolumn{2}{|c|}{ The women with GDM $(n=153)$} & \multicolumn{2}{|c|}{ Healthy Group (n=155) } \\
\hline & $\mathbf{r}$ & $\mathbf{p}$ & $\mathbf{r}$ & $\mathbf{p}$ \\
\hline PDS $^{*}$ & 0.45 & $<.001$ & 0.38 & $<.001$ \\
\hline
\end{tabular}

*: Spearman's rho

Natasha et al. (12) found no significant difference about depression symptoms prevalance between GDM and healty pregnant $(25.9 \%$ of the women with gestational diabetes and $10.3 \%$ of healthy pregnants). The difference between the outcome of our study and the literature may be due to the inclusion criteria used (24 gestational week and over).

The stress experienced by women during pregnancy period is normally seen due to physical and psychological changes. However, as the level of stress increases, the incidence of depressive symptoms increases $(3,5)$. There was a statistically significant positive and poor correlation between prenatal stress and depression in both groups for the result of our study (Table 3). In a study by Carolan-Olah and Barry (26), the prevalence of depressive symptoms increased as prenatal stress level increased. In the study of Fışkın et al. (3), also reported that psychosocial adaptation was low in high-risk pregnancies and depression symptoms were more frequent in those who had more stress.

According to the result of our study, it is assumed that the incidence of stress and depression symptoms may be higher in pregnant women with diabetes compared to healthy pregnant women. Nurses should have more attention to the symptoms of depression in women with GDM. Stress and depression which are more intense in pregnant women, GDM may increase the risk of maternal and foetal health problems in addition to diabetes. For this reason, it is important that health care professionals should be informed about the stress and depression effects in pregnant women with GDM.

\section{CONCLUSION}

As a result of this study, gestational diabetics were found to have more distress and depression symptoms. It was found that social support was not an effective on gestational stress, but it was important for depression to increase the incidence of symptoms. It was determined that depressive symptoms incidence increased as prenatal distress increased in pregnancy. According to study results, the awareness of health care providers should be increased that the women with gestational diabetes show more stress and depression symptoms than healthy pregnancies.

\section{The Declaration of Interest}

The authors received no financial support and declared no potential conflicts of interest with respect to the research, authorship and/or publication of this article.

\section{REFERENCES}

1. Çelik F, Nadirgül Köken G, Yılmazer M. Factors affecting development of depression symptoms and depression in pregnancy. Anatolian Medical Research Journal. 2013;7(2): 110-117.

2. Mermer G, Bilge A, Yücel U, Çeber E. Examination of social support perception levels during pregnancy and postpartum period. Journal of Psychiatric Nursing. 2010;1(2):71-76.

3. Fışkın G, Mecdi Kaydırak M, Yeşiltepe Oskay Ü. Psychosocial adaptation and depressive manifestations in high-risk pregnant women: Implications for clinical practice. Worldviews Evid Based Nurs. 2017; 14(1):55-64.

4. Huang T, Rifas-Shiman SL, Ertel KA, Rich-Edwards J, Kleinmen K, Gillman MW, et al. Pregnancy hyperglycemia and risk of prenatal and postpartum depressive symptoms. Paediatr Perinat Epidemiol. 2015; 29(4):281-289.

5. Karaçam Z, Ançel G. Depression, anxiety and influencing factors in pregnancy: A study in a Turkish population. Midwifery. 2007; 25:344-356.

6. Ölçer Z, Bakır N, Oskay Ü. Self-sufficiency and social support perceptions of high risk pregnants. Anatolian Nursing and Health Sciences Journal. 2016; 19(1):25-33. 
7. Grandi C, Tapia JL, Cardoso VC. Impact of maternal diabetes mellitus on mortality and morbidity of very low birth weight infants: A multicenter Latin America study. J Pediatr (Rio J). 2014; 91(3):234-241.

8. Hilden K, Hanson U, Persson M, Fadl H. Overweight and obesity: a remaining problem in women treated for severe gestational diabetes. Diabet Med. 2016; 33:1045-1051.

9. Kampmann U, Madsen LR, Skajaa GO, Iversen DS, Moeller N, Ovesen P. Gestational diabetes: A clinical update. World J Diabetes. 2015; 6(8):1065-1072.

10. Özyurt R, Aşıcıoğlu O, Gültekin T, Güngördük K, Boran B. Gestational diabetes mellitus prevalance in pregnant women who attended Istanbul Medical Education and Research Hospital Obstetrics and Gynecology Clinic. Gynecology Obstetric Pediatrics and Pediatric Surgery Journal. 2013; 5(1):7-12.

11. Şen E, Yağcan H, Dönmez S, Sevil Ü, Şirin A. Gestational diabetes and nursing care management. Gynecology and Obstetrics Magazine. 2008; 22(2):140-146.

12. Natasha K, Hussain A, Azad Khan AK. Prevalence of depression among subjects with and without gestational diabetes mellitus in Bangladesh: A hospital based study. J Diabetes Metab Disord. 2015; 14:64.

13. Kozhimannil KB, Pereira MA, Harlow BL. Association between diabetes and perinatal depression among low-income mothers. JAMA. 2009; 301(8):842-847.

14. Bitew T, Hanlon C, Kebede E, Honikman S, Onah MN, Fekadu A. Antenatal depressive symptoms and utilisation of delivery and postnatal care: A prospective study in rural Ethiopia. BMC Pregnancy Childbirth. 2017;17(1):206.

15. Biratu A, Haile D. Prevalence of antenatal depression and associated factors among pregnant women in Addis Ababa, Ethiopia: A cross-sectional study. Reprod Health. 2015;12:99.
16. Byrn MA, Penckofer S. Antenatal depresion and gestational diabetes. Nursing for Women's Health. 2013; 17(1):24-33.

17. Vırıt O, Akbaş E, Savaş HA, Sertbaş G, Kandemir H. Relation of depression and anxiety levels to social support in pregnancy. Archives of Neuropsychiatry. 2008; 45:9-13.

18. Yüksel F, Akın S, Durna, Z. Adaptation of prenatal distress scale to Turkish and factor analysis. Society for Research and Development in Nursing. 2012; 8 (3):43-45.

19. Giurgescu C, Penckofer S, Maurer MC, Bryant FB. Impact of uncertainty, social support, and prenatal coping on the psychological well-being of high-risk pregnant women. Nurs Res. 2006; 55(5):356-365.

20. Aksoy YE, Aslantekin F, Yılmaz, S. Prenatal attachment and social support in risky pregnancies. Turkey Clinics. 2016.

21. Moshki M, Cheravi K. Relationships among depression during pregnancy, social support and health locus of control among Iranian pregnant women. Int J Soc Psychiatry. 2016; 62(2):148155.

22. Daglar G, Nur N. The relation between stress coping styles with anxiety and depression. Cumhuriyet Medical Journal. 2014; 36:429-441.

23. Gümüşdağ M, Apay SE, Özorhan EY. Comparison of psychosocial health of pregnant and non-risky patients. Journal of Health Sciences and Professions. 2014; 1(2):32-42.

24. Silveira ML, Whitcomb BW, Pekow P, Braun B, Markenson G, Dole N, et al. Perceived psychosocial stress and glucose intolerance among pregnant Hispanic women. Diabetes Metab. 2014; 40(6):466-475.

25. Golden SH, Lazo M, Carnethon M, Bertoni AG, Schreiner PJ, Diez Roux AV, et al. Examining a bidirectional association between depressive symptoms and diabetes. JAMA. 2008; 299(23):2751-2759.

26. Carolan-Olah M, Barry M. Antenatal stress: An Irish case study. Midwifery. 2013; 30(3):310-316. 